\title{
Influence of Human Capital, Structural Capital and Relational Capital toward Bank Service Performance and Customer Satisfaction
}

\author{
$1^{\text {st }}$ Usup Riassy Christa ${ }^{1}, 2^{\text {nd }}$ Tresia Kristiana ${ }^{2}$ \\ \{usupriassychrista@gmail.com ${ }^{1}$, tresiakristiana@yahoo.co.id ${ }^{2}$ \} \\ Departement of Economic University of Palangkaraya (UPR) Palangka Raya, Indonesia ${ }^{1}$, Departement \\ of Social and Politic Palangkaraya Cristian University (UNKRIP) Palangka Raya, Indonesia ${ }^{2}$
}

\begin{abstract}
This study analyzed the influence of interrelated variables to explain the effect of human capital, structural capital, and relation capital toward bank service performance and customer satisfaction at commercial banks in Central Kalimantan. The hypothesis were tested by Partial Least Square (PLS) are the direct and indirect variable influence of human capital to variable relational capital, structural capital, bank service performance and customer satisfaction. This research approach uses quantitative approach through survey method. The study population is all branch offices and sub-branches of Central Kalimantan Commercial Bank with total sample of 42 office units in four (4) banks, determined using purposive sampling method. Research respondents were 5 bank employees and 5 customers were taken from each research sample unit. The findings of the study support the opinion that the relationship between human capitals, structural capital, and relation capital significantly form the performance of bank service (servperf) and customer satisfaction. However, research results have not been generalizable to all types of bank services.
\end{abstract}

Keywords: Intellectual Capital, Human Capital, Structural Capital, Relational Capital, Bank Service Performance And Customer Satisfaction.

\section{Introduction}

Each company aims to achieve effective and sustainable performance, but the competitiveness of competition and limited availability of corporate resources are two sides of the contradictory, but affect the achievement of performance. Management of internal organizational resources (human capital, structural capital and relational capital) through the proper optimization of empowerment of internal resources of the company and the correct procedures, can encourage the achievement of effective performance and competitiveness.

An important perspective in today's banking services business is that banks always provide excellent services to customers and maintain high quality of service and customer satisfaction. This has indeed been done by commercial banks, but these efforts have not been maximized, constrained by the limited availability of resources (human capital as intellectual assets) following the example. Some components, such as multi-leveled equations, graphics, and tables are not prescribed, although the various table text styles are provided. The formatter will need to create these components, incorporating the applicable criteria that follow. That impact on the ability of banks (human capital as a manager of intellectual assets) to mobilize and utilize 
intellectual capital in an integrated manner. The problems of commercial banks in Central Kalimantan need immediate handling to ensure the existence of banks are maintained in good condition (healthy banks) and not just exist, but to find the right solution so as to overcome the problems that are being experienced. Management of intellectual assets or intangible assets of banks through the empowerment of human capital - strategic human resources, must be supported by the availability of structural capital, relational capital and integrated will be the best solution to overcome the limitations of the resources in the competition while increasing the ability of banks in achieving the performance effective or superior performance (competitiveness)

The demand for modern industrialization is characterized by the creation of value derived from intangible assets and is known as Intellectual Capital (IC), which is the knowledge and skills that are owned and attached to individual employees, relationships social / relational depth with consumers, as well as a culture of sharing knowledge that enables innovation and strategic change, will encourage the creation of competitiveness and competitive advantage (competitiveness). The above description, a reason and basic consideration for researchers that this research needs to be done.

The research problem is "How is the main component role of Intellectual Capital (IC): Human Capital, in influencing the performance of Bank Service and Satisfaction of Commercial Bank Customers in Central Kalimantan". To answer the problem of research, then proposed problem formulation as follows:

1. Does the increase of Human Capital bank significantly influence the improvement of Relational Capital bank?

2. Is the increase of Human Capital bank significantly influence to increase Structural Capital bank?

3. Does the increase in Relational Capital of banks have a significant effect on the increase of Structural Capital bank?

4. Does the Bank's Human Capital increase significantly affect the improvement of Bank Service Performance?

5. Does the increase in Relational Capital of banks significantly affect the improvement of Bank Service Performance?

6. Does Structural Capital bank increase significantly influence the improvement of Bank Service Performance?

7. Is the increase of Human Capital bank significantly influence the increase of Bank Customer Satisfaction?

8. Does the Bank Service Performance Improvement significantly affect the improvement of Bank Customer Satisfaction?

\section{Methodology}

The population in this study are all branch offices and sub-branches of commercial banks operating in the territory of Central Kalimantan Province. The sampling technique using purposive sampling refers to Roscoe in Sekaran (2006) Sugiyono (2008) and Sugiyanto (2006), determined 42 units of branch offices and sub-branches of commercial banks as research samples with 420 internal respondents (bank employees) and external respondents customers / customers) of commercial banks in Central Kalimantan with 384 respondents 
elected, as they meet the requirements and have been filled in completely as the data being analyzed.

Based on the conceptual framework of research, there are two groups of variables: variables that affect other variables in the model as exogenous variables and variables that are influenced as endogenous variables. In this study, exogenous variables are (1) Human Capital; (2) Relational Capital; (3) Structural Capital. Endogenous variables are (1) Performance of Bank Service and (2) Customer Satisfaction

The research instrument used is a questionnaire containing a number of written questions about the items of the research variables, in order to obtain respondent perceptions. Answers to this question were measured using a five-point Likert scale (1-5) including: (1) strongly disagree / STS; (2) disagree / TS; (3) hesitation / RR; (4) agree / S; (5) strongly agree / SS. In measuring the research variables, respondents are asked to state their perceptions by choosing one of the alternative answers that are considered most suitable or in accordance with what is felt or experienced. In addition to using questionnaires, interviews were conducted to obtain information from a number of key persons selected as informants

Techniques of data analysis using descriptive analysis, to know the characteristics of respondents and descriptions of respondents to the indicators of each research variable. Description of each indicator is expressed in percentage of frequency value and average value, so as to obtain the perception of respondent's perception of the indicators as a variable formers. While for hypothesis testing and produce good research model (fit), this research uses Structural Equation Modeling (SEM) with Partial Least Square (PLS) structural equation approach.

\section{Research Result}

\section{A. Characteristic of respondents}

Table1. Characteristic Respondent Internal: Bank Employes

\begin{tabular}{|c|l|l|l|}
\hline No. & Characteristic respondent & $\begin{array}{c}\text { Number } \\
\text { (individu) }\end{array}$ & $\begin{array}{c}\text { Percen } \\
\mathbf{t}(\boldsymbol{\%})\end{array}$ \\
\hline 1 & Umur & & \\
\hline & $20-30$ tahun & 45 & 23,4 \\
\hline & $31-40$ tahun & 68 & 35,4 \\
\hline & $41-50$ tahun & 58 & 30,2 \\
\hline & $>50$ tahun & 21 & 10,9 \\
\hline 2 & Jenis Kelamin & & \\
\hline & Laki - laki & 75 & 39,1 \\
\hline & Perempuan & 117 & 60,9 \\
\hline 3 & Kedudukan di Pekerjaan & & \\
\hline & Kadiv. operasional & 30 & 15,6 \\
\hline & Staf div. kredit \& analis kredit & 65 & 33,9 \\
\hline & Teller, Customer Service & 97 & 50,5 \\
\hline 4 & Masa Kerja & & \\
\hline & $<5$ tahun & 35 & 18,2 \\
\hline & $5-10$ tahun & 70 & 36,5 \\
\hline
\end{tabular}




\begin{tabular}{|c|l|l|l|}
\hline No. & Characteristic respondent & $\begin{array}{c}\text { Number } \\
\text { (individu) }\end{array}$ & $\begin{array}{c}\text { Percen } \\
\mathbf{t}(\boldsymbol{\%})\end{array}$ \\
\hline & $10-20$ tahun & 57 & 29,7 \\
\hline & $>$ 20 tahun & 30 & 15,6 \\
\hline 5 & Tingkat Pendidikan & & \\
\hline & SMU (setara) & 42 & 21,9 \\
\hline & Diploma III (D3)/(setara) & 33 & 17,2 \\
\hline & Strata satu (S1) & 108 & 56,2 \\
\hline & Strata dua (S2) & 9 & 4,7 \\
\hline
\end{tabular}

Resource: Primer Data

The internal respondent characteristics of the majority of employees of the bank by age, aged between $31-40$ years are 68 people $(35.4 \%)$, followed by 58 people $(30.2 \%)$ aged $41-50$ years, $45(23.4 \%)$ aged between 20 to 30 years and 21 people $(10.9 \%)$ are over 50 years old. The percentage of the largest age group of respondents was at productive age (31 - 40) years, on the contrary the lowest percentage was at the age before consecution i.e. age above 50 years.

The description reflects the characteristics of bank-rich commercial banks in Central Kalimantan based on their age in the productive age condition which means that employees of commercial banks in Central Kalimantan have the opportunity to improve their professionalism which will affect individual capabilities in transforming knowledge and skills to tasks so as to produce performance more increased.

Table 2. Characteristic Respondent External: Custamers

\begin{tabular}{|l|l|l|l|}
\hline No. & Karakteristik Responden & $\begin{array}{l}\text { Jumlah } \\
\text { (orang) }\end{array}$ & $\begin{array}{l}\text { Persentasi } \\
(\%)\end{array}$ \\
\hline $\mathbf{1}$ & Umur & & \\
\hline & $<20$ tahun & 11 & 5,7 \\
\hline & $21-30$ tahun & 38 & 19,7 \\
\hline & $31-40$ tahun & 77 & 40,1 \\
\hline & $41-50$ tahun & 55 & 28,6 \\
\hline & $>$ 50 tahun & 31 & 16,1 \\
\hline $\mathbf{2}$ & Jenis Kelamin & & \\
\hline & Laki - laki & 88 & 45,8 \\
\hline & Perempuan & 104 & 54,2 \\
\hline $\mathbf{3}$ & Lama sebagai Nasabah & & \\
\hline & $<5$ tahun & 55 & 28,6 \\
\hline & $5-10$ tahun & 84 & 43.8 \\
\hline & $>10$ tahun & 53 & 27,6 \\
\hline $\mathbf{4}$ & Tingkat Pendidikan & & \\
\hline & SMU (setara) & 22 & 11,5 \\
\hline & Diploma III (D3) & 33 & 17,2 \\
\hline & Strata satu (S1) & 72 & 37,5 \\
\hline & Strata dua (S2) & 47 & 24,4 \\
\hline & Strata tiga (S3) & 18 & 9,4 \\
\hline $\mathbf{5}$ & Jenis Pekerjaan & & \\
\hline & Pelajar/Mahasiswa & 28 & 14,3 \\
\hline & & & \\
\hline & & & \\
\hline & & & \\
\hline & & & \\
\hline & & & \\
\hline & & & \\
\hline
\end{tabular}




\begin{tabular}{|l|l|l|l|}
\hline No. & Karakteristik Responden & $\begin{array}{l}\text { Jumlah } \\
\text { (orang) }\end{array}$ & $\begin{array}{l}\text { Persentasi } \\
(\boldsymbol{\%})\end{array}$ \\
\hline & PNS & 89 & 46,4 \\
\hline
\end{tabular}

Resource: Primer Data

Table 2 describe the condition of external respondents by age. The majority of customers / clients are clients aged between 31 - 40 years old as many as 77 people $(41.1 \%)$, followed by 55 people $(28.6 \%)$ aged $41-50$ years old, as many as 38 people $(19.7 \%)$ aged between <20 years $(5.7 \%)$ as many as 11 people and 31 people $(16.1 \%)$ aged over 50 years. Of the five age groups, it is the age of 31-40 years, while the lowest percentage is in the age group below 20 years

The description describes the characteristics of customers of commercial banks in Central Kalimantan is a potential customer and has a significant influence on the existence of business (Commercial) business in Central Kalimantan based on Age, because it is at the level of productive age (31-40) years.

\section{B. Test of Validity and Reliability of Research Instruments}

Validity test is conducted to determine whether the measuring instrument / instrument used is really appropriate to measure the measured object. While the reliability test carried out to determine the reliability of the measuring tool or the consistency of the measuring instrument, if used to measure the same object more than twice. Result of validity test and reliability of research instrument with reflexive indicator, showing result of measurement of convergence validity, composite reliability and discriminant validity as follows:

a. Convergence validity test results (Table IV) Obtained all outer loading value of constructor indicator has bigger value than $0.5(\geq 0.5)$ so that it can be concluded that the measurement has fulfilled the requirement of convergent validity.

b. Composite reliability test results (Table V) Obtained by all composite reliability values: $\mathrm{X} 1$ of $0.862, \mathrm{Y} 1$ of 0.888 and $\mathrm{Y} 2$ of 0.759 indicates a value greater than 0.7 thus all indicator variables are the constructor gauge. That is, each research instrument used is a reliable or consistent instrument.

c. Discriminant test results validity shown from AVE root value (average variance extracted) in Table VI. Each construct shows a value greater than the correlation score between its latent variables (value $\mathrm{X} 1=0.823$ greater than $\mathrm{Y} 1=0.362$ and $\mathrm{Y} 2=0.434)$, (value $\mathrm{Y} 1=$ 0.893 greater than $\mathrm{X} 1=0.362$ and $\mathrm{Y} 2=0.418$ ) and (value $\mathrm{Y} 2=0.720$, greater than $\mathrm{X} 1=$ 0.434 and $\mathrm{Y} 1=0.418$ ). This means that all constructs involved in the study meet the criteria of discriminant validity.

\section{Results of Descriptive Analysis}

\section{Description of Human Capital Variables (HC) / X1}

Results of respondents' answers to the complete human capital variable can be seen in the table as follows:

Table 3. Description Of Human Capital Variable (HC)

\begin{tabular}{|l|l|l|l|l|l|l|}
\hline \multirow{2}{*}{ Indicator } & \multicolumn{4}{|l|}{ Percentation of respondent answer (\%) } & \multirow{2}{*}{ mean } \\
\cline { 2 - 7 } & STS & TS & RR & S & SS & \\
\hline Kapabilitas Karyaw. $\left(\mathrm{X}_{11}\right)$ & 1.7 & 15.6 & 36.1 & 30.6 & 15.8 & \multirow{3}{*}{$\mathbf{3 . 4 3}$} \\
\hline
\end{tabular}




\begin{tabular}{|l|l|l|l|l|l|l|}
\hline Kepuasan Karyw. $\left(\mathrm{X}_{12}\right)$ & 1.3 & 17.4 & 36.7 & 32.6 & 11.9 & $\mathbf{3 . 4 1}$ \\
\hline Kesinambungan Karyaw. $\left(\mathrm{X}_{13}\right)$ & 1.3 & 16.9 & 35.7 & 32.0 & 14.5 & $\mathbf{3 . 3 6}$ \\
\hline
\end{tabular}

Resource: Primer Data

The average score of Human Capital indicator is: employee capability, employee satisfaction and employee sustainability show score above 3 i.e. (3.41) and dominant indicator with highest score is employee capability (X11). With a mean score of 3.38 including the moderate category indicates that employee perceptions of the ability to transform individual employee knowledge and skills to tasks have increased considerably.

\section{Description of Variabel Relational Capital (RC)}

Table 4. Description Variabel Relational Capital (RC)

\begin{tabular}{|c|c|c|c|c|c|c|}
\hline \multirow{2}{*}{ Indikator } & \multicolumn{5}{|c|}{ Prosentase Jawaban Responden (\%) } & \multirow[b]{2}{*}{ Mean } \\
\hline & STS & TS & $\mathbf{R R}$ & $\mathbf{S}$ & SS & \\
\hline $\begin{array}{l}\text { Pelanggan/ } \\
\text { customer }\left(\mathrm{X}_{21}\right)\end{array}$ & 1.4 & 17.1 & 33.5 & 36.8 & 12.0 & 3.39 \\
\hline $\begin{array}{l}\text { Sistem } \\
\text { Partner/ } \\
\text { Jaringan }\left(\mathrm{X}_{22}\right) \\
\end{array}$ & 1.2 & 17.6 & 32.4 & 35.6 & 13.2 & 3.42 \\
\hline \multicolumn{6}{|c|}{ Indeks Persepsi Rerata Variabel Relational Capital $\left(\mathrm{X}_{2}\right)$} & 3.40 \\
\hline
\end{tabular}

Resource: Primer Data

The average score of Human Capital indicator is: employee capability, employee satisfaction and employee sustainability show score above 3 i.e. (3.40) and dominant indicator with highest score is employee capability (X22). With a mean score of 3.38 including the moderate category indicates that employee perceptions of the ability to transform individual employee knowledge and skills to tasks have increased considerably.

\section{Descriptions Variabel Structural Capital (SC)}

Table 5. Description Of Structural Capital (SC)

\begin{tabular}{|c|c|c|c|c|c|c|}
\hline \multirow{2}{*}{ Indikator } & \multicolumn{5}{|c|}{ Prosentase Jawaban Responden (\%) } & \multirow{2}{*}{ Mean } \\
\hline & STS & TS & $\mathbf{R R}$ & $\mathbf{S}$ & SS & \\
\hline Budaya Org. $\left(\mathrm{X}_{31}\right)$ & 1.6 & 17.5 & 33.9 & 35.5 & 12.1 & 3.39 \\
\hline $\begin{array}{l}\text { Kekayaan } \\
\text { intelektual }\left(\mathrm{X}_{32}\right)\end{array}$ & 1.2 & 17.6 & 32.5 & 35.6 & 13.2 & 3.42 \\
\hline Sistem Op. $\left(\mathrm{Y}_{33}\right)$ & 1.6 & 17.4 & 33.8 & 35.5 & 12.1 & 3.39 \\
\hline \multicolumn{6}{|c|}{ Indeks Persepsi Rerata Var. Structural Capital $\left(\mathbf{X}_{3}\right)$} & 3.40 \\
\hline
\end{tabular}

Resource: Primer Data

Table 5 above the average score of the Human Capital indicator shows the score above three (3.40) and the dominant indicator with the highest score is the employee's capability (X32). A mean score of 3.38 including the moderate category indicates that employees' 
perceptions of the ability to transform individual employee knowledge and skills to tasks have increased considerably.

\section{Bank Service Performance (SP)}

Table 6. Description Of Bank Service Performance (SP)

\begin{tabular}{|c|c|c|c|c|c|c|}
\hline \multirow{2}{*}{ Indikator } & \multicolumn{5}{|c|}{ Prosentase Jawaban Responden (\%) } & \multirow{2}{*}{ Mean } \\
\hline & STS & TS & $\mathbf{R} \mathbf{R}$ & $\mathbf{S}$ & SS & \\
\hline Tangibles $\left(\mathrm{Y}_{11}\right)$ & 1.6 & 17.6 & 16.8 & 35.5 & 12.6 & 3.37 \\
\hline Responsiveness $\left(\mathrm{Y}_{12}\right)$ & 1.8 & 12.6 & 38.4 & 32.7 & 32.7 & 3.38 \\
\hline Assurance $\left(\mathrm{Y}_{13}\right)$ & 1.4 & 16.3 & 36.9 & 35.6 & 9.8 & 3.36 \\
\hline Reliability $\left(\mathrm{Y}_{14}\right)$ & 7.7 & 19.4 & 35.4 & 26.0 & 15.2 & 3.37 \\
\hline Empathy $\left(\mathrm{Y}_{15}\right)$ & 1.4 & 17.5 & 35.9 & 32.3 & 13.3 & 3.38 \\
\hline \multicolumn{6}{|c|}{ Indeks rerata persepsi variabel Kinerja Layanan Bank $\left(\mathbf{Y}_{1}\right)$} & 3.37 \\
\hline
\end{tabular}

Resource: Primer Data

The average score of Bank service performance: tangibles, responsiveness, assurance, reliability, empathy show score above 3 i.e. (3.37) and dominant indicator with highest score is employee capability (X12). A mean score of 3.37 including the moderate category indicates that employee perceptions of the ability to transform individual employee knowledge and skills to tasks have increased considerably.

\section{Variable of Custamer Service (CS)}

Table 7. Description Of Custamer Service (CS)

\begin{tabular}{|l|l|l|l|l|l|l|}
\hline \multirow{2}{*}{ Indikator } & \multicolumn{3}{|l|}{ Prosentase Jawaban Responden (\%) } & Rata-rata \\
\cline { 2 - 6 } & STS & TS & RR & S & SS & Skor \\
\hline Y21 & 1.0 & 17.2 & 36.5 & 32.3 & 13.0 & 3.39 \\
\hline Y22 & 0.5 & 15.1 & 39.6 & 29.2 & 15.6 & 3.44 \\
\hline Y23 & 0.5 & 18.8 & 35.4 & 29.7 & 15.6 & 3.41 \\
\hline Y24 & 2.6 & 18.8 & 39.6 & 23.4 & 15.6 & 3.31 \\
\hline Y25 & 1.6 & 15.1 & 39.6 & 31.7 & 12.0 & 3.37 \\
\hline Y26 & 2.6 & 22.4 & 35.4 & 30.7 & 8.9 & 3.21 \\
\hline Y27 & 0.5 & 18.8 & 39.6 & 29.1 & 12.0 & 3.33 \\
\hline Y28 & 0.5 & 18.8 & 39.6 & 25.5 & 15.6 & 3.37 \\
\hline Y29 & 2.6 & 18.8 & 35.4 & 31.2 & 12.0 & 3.31 \\
\hline Y210 & 2.6 & 18.8 & 35.4 & 31.2 & 12.0 & 3.31 \\
\hline Y211 & 0.5 & 18.8 & 39.6 & 29.1 & 12.0 & 3.33 \\
\hline Y212 & 0.5 & 15.1 & 35.4 & 33.4 & 15.6 & 3.49 \\
\hline Y213 & 2.6 & 18.8 & 32.8 & 30.2 & 15.6 & 3.37 \\
\hline Y214 & 2.6 & 15.1 & 35.4 & 31.3 & 15.6 & 3.42 \\
\hline Y215 & 0.5 & 15.1 & 35.4 & 37.0 & 12.0 & 3.45 \\
\hline Y216 & 2.6 & 15.1 & 39.6 & 30.7 & 12.0 & 3.34 \\
\hline
\end{tabular}




\begin{tabular}{|l|l|l|l|l|l|l|}
\hline Y217 & 2.6 & 18.8 & 39.6 & 27.0 & 12.0 & 3.27 \\
\hline Y218 & 0.5 & 15.1 & 35.4 & 37.0 & 12.0 & 3.45 \\
\hline Y219 & 0.5 & 15.1 & 35.4 & 33.4 & 15.6 & 3.49 \\
\hline Y220 & 2.6 & 15.1 & 39.6 & 27.1 & 15.6 & 3.38 \\
\hline Indeks persepsi rerata variabel Kepuasan Pelanggan $\left(\mathbf{Y}_{\mathbf{2}}\right)$ & & $\mathbf{3 . 3 7}$ \\
\hline
\end{tabular}

Resource: Primer Data

The average score of Human Capital indicator is: employee capability, employee satisfaction and employee sustainability show score above 3 i.e. (3.37) and dominant indicator with highest score is employee capability (Y212 and Y219). With a mean score of 3.37 including the moderate category indicates that employee perceptions of the ability to transform individual employee knowledge and skills to tasks have increased considerably.

\section{Test of Linearity Assumptions}

\section{Test Result of Linearity Assumption}

Testing Assumption The linearity of relationships among variables in this study using Curve Fit method and test results can be seen in Table VIII as follows:

Table 8. Test Of Linierity Assumsion

\begin{tabular}{|l|l|l|l|}
\hline \multicolumn{2}{|l|}{ Hubungan Variabel } & Pengujian Model Linier & Kesimpulan \\
\hline HC & RC & Model Linier Signifikan & Linier \\
\hline HC & SC & Model Linier Signifikan & Linier \\
\hline RC & SC & Model Linier Signifikan & Linier \\
\hline HC & SP & Model Linier Signifikan & Linier \\
\hline RC & SP & Model Linier Signifikan & Linier \\
\hline SC & SP & Model Linier Signifikan & Linier \\
\hline HC & CS & Model Linier Signifikan & Linier \\
\hline SP & CS & Model Linier Signifikan & Linier \\
\hline
\end{tabular}

Resource: Primer Data

Based on the results of the linearity assumption test as shown in Table 8 above, it is known that all linear models are significant. This explains that the linearity assumption in this research model is met, meaning that analysis can proceed.

\section{Testing the Goodness of Fit Structural Model (Inner Model)}

The Goodness of Fit test of the structural model in the inner model uses predictiverelevance $(\mathrm{Q} 2)$ values and the calculation is valued based on the value of $\mathrm{R} 2$. The $\mathrm{R} 2$ value of each endogenous variable in this study is shown as Table IX following:

Table 9. Endogen Variable Of $\mathrm{R}^{2}$ Score

\begin{tabular}{|l|l|}
\hline Variabel Endogen & R-square \\
\hline Relational Capital $(\mathrm{RC})$ & 0,131 \\
\hline Structural Capital $(\mathrm{SC})$ & 0,267 \\
\hline Bank Service Performent $(\mathrm{SP})$ & 0,498 \\
\hline Custamer Service $(C S)$ & 0,142 \\
\hline
\end{tabular}


Goodness of Fit test of structural model in inner model using predictive-relevance value (Q2) is obtained based on R-square value of each endogenous variable as shown in Table 9 above. The predictive-relevance $\left(\mathrm{Q}_{2}\right)$ value is obtained using the following formula:

$\mathrm{Q} 2=1-(1-\mathrm{R} 12)(1-\mathrm{R} 22) \ldots(1-\mathrm{Rp} 2)$

$\mathrm{Q} 2=1-(1-0.131)(1-0.267)(1-0.498)(1-0.142)$

$\mathrm{Q} 2=0.726$

The calculation results show a predictive-relevance (Q2) value of 0.726 or $72.6 \%$, meaning that the model deserves to be said to have a relevant predictive value. The predictive relevance value of 0.726 indicates the diversity of data that can be explained by the model is $72.6 \%$ or in other words, the information contained in the data can be explained by the model by $72.6 \%$. While the rest of $27.4 \%$ is explained by other variables that have not been contained in the model and error.

\section{E. Hypothesis Testing Results}

The results of hypothesis testing based on the test results of Loading Factor (outer model) to show the weight of each indicator as a measure of each variable. The indicator with the largest loading factor shows the indicator as the strongest (dominant) variable. The results of hypothesis testing (Inner Model) with $\mathrm{t}$ test (t-test) on each lane of direct and indirect influence partially. The result of complete analysis is found in result of Partial Least Square (PLS) analysis as seen in Appendix 5 and Table 5.10 presents result of hypothesis test of direct influence, Table 5.11 presents the result of indirect effect hypothesis testing. Complete see Table 5.10 below:

Table 10. Test Result Of Influence Between Researches Variable Hypotesis

\begin{tabular}{|c|c|c|c|c|c|c|}
\hline \multirow[b]{2}{*}{ Hipotesis } & \multicolumn{3}{|c|}{ Pengaruh antar Variabel } & \multirow[b]{2}{*}{$\begin{array}{l}\text { Koefisien } \\
\text { Jalur }\end{array}$} & \multirow[b]{2}{*}{$p$-value } & \multirow[b]{2}{*}{ Keterangan } \\
\hline & Var.Bebas & Terhadap & $\begin{array}{l}\text { Var. } \\
\text { Terikat }\end{array}$ & & & \\
\hline $\mathrm{H}_{1}$ & $\mathrm{HC}$ & $\rightarrow$ & $\mathrm{RC}$ & 0.362 & 0.007 & Signifikan \\
\hline $\mathbf{H}_{2 \mathrm{a}}$ & $\mathrm{HC}$ & $\rightarrow$ & SC & 0.326 & 0.011 & Signifikan \\
\hline $\mathbf{H}_{3}$ & $\mathrm{RC}$ & $\rightarrow$ & $\mathrm{SC}$ & 0.300 & 0.033 & Signifikan \\
\hline $\mathbf{H}_{4 \mathrm{a}}$ & $\mathrm{HC}$ & $\rightarrow$ & SP & 0.472 & 0.000 & Signifikan \\
\hline $\mathbf{H}_{5 \mathrm{a}}$ & RC & $\rightarrow$ & SP & 0.147 & 0.321 & \begin{tabular}{|l|} 
Non \\
Signifikan
\end{tabular} \\
\hline $\mathbf{H}_{6 a}$ & SC & $\rightarrow$ & SP & 0.258 & 0.033 & Signifikan \\
\hline $\mathbf{H}_{7 \mathbf{a}}$ & $\mathrm{HC}$ & $\rightarrow$ & CS & 0.178 & 0.355 & \begin{tabular}{|l|} 
Non \\
Signifikan
\end{tabular} \\
\hline $\mathbf{H}_{8}$ & SP & $\rightarrow$ & $\mathrm{CS}$ & 0.238 & 0.035 & Signifikan \\
\hline $\mathbf{H}_{2 \mathrm{~b}}$ & $\mathrm{HC}$ & $\mathrm{RC}$ & $\mathrm{SC}$ & 0.109 & & Signifikan \\
\hline $\mathbf{H}_{4 \mathrm{~b}}$ & $\mathrm{HC}$ & $\mathrm{SC}$ & SP & 0.084 & & Signifikan \\
\hline $\mathbf{H}_{5 \mathrm{~b}}$ & $\mathrm{RC}$ & $\mathrm{SC}$ & SP & 0.077 & & Signifikan \\
\hline $\mathbf{H}_{5 \mathrm{c}}$ & $\mathbf{R C}$ & $\mathbf{S P}$ & CS & 0.035 & & \begin{tabular}{|l|} 
Non \\
Signifikan \\
\end{tabular} \\
\hline $\mathrm{H}_{6 \mathrm{~b}}$ & $\mathrm{SC}$ & SP & CS & 0.061 & & Signifikan \\
\hline $\mathbf{H}_{7 \mathrm{~b}}$ & $\mathrm{HC}$ & SP & CS & 0.112 & & Signifikan \\
\hline
\end{tabular}


Keterangan: Signifikan ( $p$-value < cut Off 0.05); Non Signifikan ( $p$-value > cut Off 0.05)

The results of hypothesis testing based on the test of line diagram model in Partial Least Square (PLS) of 8 (eight) hypotheses of research, there are 5 (five) significant variables, receive $(\mathrm{H} 1, \mathrm{H} 2 \mathrm{a}, \mathrm{H} 2 \mathrm{~b}, \mathrm{H} 3, \mathrm{H} 4 \mathrm{a}, \mathrm{H} 4 \mathrm{~b}, \mathrm{H} 5 \mathrm{~b}, \mathrm{H} 6 \mathrm{a}, \mathrm{H} 7 \mathrm{~b}$ and $\mathrm{H} 8$ ) and 3 (three) variables are not significant, meaning $\mathrm{H} 5 \mathrm{a}, \mathrm{H} 7 \mathrm{a}$ and $\mathrm{H} 5 \mathrm{c}$ are not accepted (rejected) and can be explained as follows:

1. H1: Increasing the quality of Human Capital bank, it will increasingly be able to improve the quality of Relational Capital. The test results showed that the value of the coefficient of $\mathrm{HC}$ variable path to $\mathrm{RC}$ is 0.362 with the significant (p-value) of 0.007 smaller than 0.5 (<0.05). This means that Human Capital has a significant effect on Relational Capital, so $\mathrm{H} 1$ is accepted.

2. H2a: Increasing the quality of Human Capital bank, it will increasingly be able to improve the quality of Structural Capital. The test results showed that the coefficient value of $\mathrm{HC}$ variable path to SC of 0.326 with a significance level (p-value) of 0.011 is greater than $0.5(<0.05)$. This means that Human Capital has a significant effect on Structural Capital, so $\mathrm{H} 2 \mathrm{a}$ is accepted.

3. H2b: Increasing the quality of Human Capital bank, it will be able to improve the quality of Structural Capital through Mediation Relational Capital. The test result showed that the coefficient value of $\mathrm{HC}$ variable path to SC through RC equal to 0,109 . Since the path coefficient is positive, it indicates the indirect effect of both directions. This means that Human Capital has no direct effect on Structural Capital, so H2b is accepted.

4. H3: Increasing the quality of Relational Capital of the bank, it will increasingly be able to improve the quality of Structural Capital. The test results showed that the coefficient value of RC variable path to RC of 0.300 with a significance level (p-value) of 0.033 greater than $0.005(<0.05)$. This means that Relational Capital effect on Structural Capital, so $\mathrm{H} 3$ accepted.

5. H4a: "Increasing the quality of Human Capital bank, it will increasingly be able to improve the quality of Service Performance Bank". The test result showed that the coefficient value of $\mathrm{HC}$ variable path to SP is 0,472 with p-value equal to $0.000(<0.05)$, meaning Human Capital has significant effect to Bank Service Performance, so H4a is accepted.

6. H4b: "Increasing the quality of Human Capital bank, it will increasingly be able to improve the quality of Service Performance of the bank through Structural Capital mediation". Test results showed that the value of the path coefficient of HC variable to SP of 0.084 , because the coefficient of the path marked positive, indicating the indirect effect of both directions. This means that Human Capital has no direct effect on Structural Capital, so H4b is accepted.

7. H5a: "Increasing the quality of Relational Capital of the bank, it will increasingly be able to improve the Quality of Service Performance Bank". The test results showed that the coefficient value of the $\mathrm{RC}$ variable path to $\mathrm{SP}$ of 0.147 with $\mathrm{p}$-value of 0.3 .21 is greater than 0.05 (> 0.05), meaning that Relational Capital has no significant effect on the Service Performance of the Bank, so H5a is rejected

8. H5b: "Increasing the quality of Relational Capital of banks, it will increasingly be able to improve the quality of service performance of banks through Structural Capital mediation". The test results showed that the coefficient value of the RC variable path to 
$\mathrm{SP}$ is 0.077 , because the path coefficient is positive, indicating the indirect effect of both directions. This means that Relational Capital affects the performance of bank services through Structural Capital, so H5b is accepted.

9. H5c: "The increased quality of Relational Capital bank, it will increasingly be able to increase the level of Customer Satisfaction through mediation Performance Banking". The test results showed that the coefficient value of the RC variable path to CS is 0.035 , because the path coefficient is positive, indicating the indirect effect of both directions. It means Relational Capital has no significant effect on Customer Satisfaction level through Bank Service Performance, so H5b is rejected.

10. H6a: "Increasing the quality of Structural Capital bank, it will increasingly be able to improve the quality of Service Performance Bank". The test results showed that the value of the coefficient of the SC variable path to SP of 0.362 with p-value of $0.007(<0.05)$, meaning that Human Capital has an effect on Relational Capital, so H1 is accepted.

11. H6b: "Increasing the quality of Structural Capital bank, it will increasingly be able to increase the level of Customer Satisfaction through mediation of Bank Service Performance". The test results showed that the coefficient value of the variable path of SC to CS is 0.061 , because the path coefficient is positive, indicating the indirect effect of both directions. This means Structural Capital affect the level of Customer

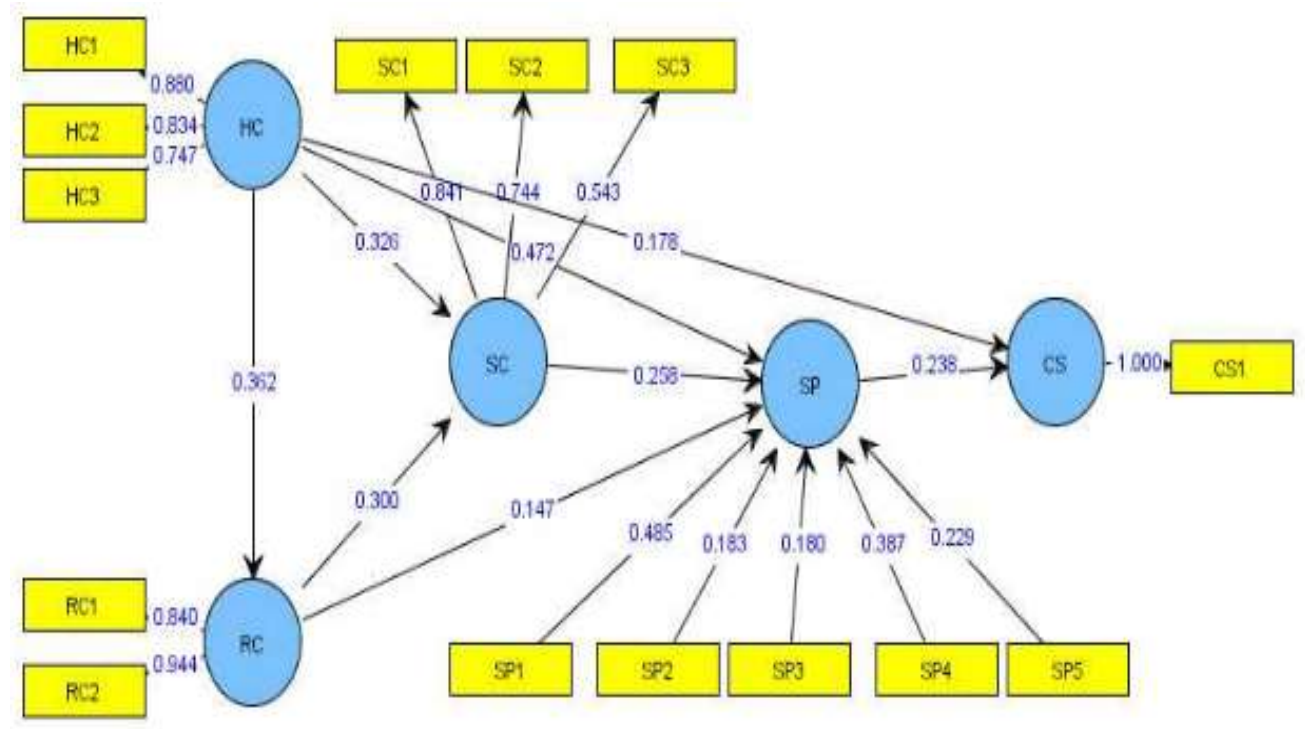

Satisfaction.

\section{Conclusions and recommendations}

Based on the results of theoretical, empirical and research studies both quantitatively and descriptively as described in the previous chapters, it can be drawn some conclusions and suggestions from the results of this study. These conclusions and suggestions can be put forward as follows: 


\section{A. Conclusion}

1. Improving the quality of Human Capital resulted in the improvement of Relational Capital quality. Improved Human Capital Capability encourages the enhancement of individual employee productivity capabilities, in terms of their ability to communicate (soft skills) or the ability to communicate their knowledge (competence) and skills (work) (professional), so as to build a better relationship / relational value in the form of cooperation or continuous partnership with customers.

2. Improving the quality of Human Capital leads to an increase in the quality of Structural Capital. It can be interpreted that improving the quality of Human Capital will improve the capability of individual employees to transform their knowledge and skills on nonhuman assets. Professional employees will be able to utilize various physical facilities of bank services such as information technology (IT) machines, data-based equipment, organizational structures and other physical facilities, and contribute to supporting the productive process of the organization (bank) in service so as to improve the quality of service bank. Improving service quality has an impact on increasing profitability and overall bank performance.

3. Improving the quality of Relational Capital caused an increase in Structural Capital performance. The potential utilization of available customer capital is a market opportunity (potential market), if managed in such a way as to be appropriate and correct by the bank, it will be able to increase the profitability (profit-value) of bank better for bank and customer. Thus, a win-win sustainable relation (sustainable) is established between the internal (stakeholder) bank and the external (stakeholder) customers.

4. Improving the quality of Human Capital leads to the improvement of Bank Service Performance Quality through Structural Capital mediation. Should high-skilled employees (professionals) will contribute better in driving the improvement of the Bank Service Performance, even though it has to go through a series of transformation processes of knowledge and skills through Structural Capital mediation. The role of Structural Capital collectively encourages the expansion of Human Capital's knowledgeexperience through the support of infrastructure and financing that bridges between Human Capital and the Bank Service Performance.

5. Improving the quality of Relational Capital is able to drive the improvement of Bank Service Performance Quality, through Structural Capital mediation. It explains that, as much or as good as any potential customer-Relational Capital available, will not cause changes to the high fluctuations in the quality of the Bank's Service Performance, except with the support of Structural Capital (routine operational centre) role through a series of service processes (main aspects of operations) a service organization, especially the banking services industry of commercial banks in Central Kalimantan.

6. Structural Capital improvements resulted in improved quality of Bank Service Performance. Structural Capital of high quality, capable of supporting the employee productivity process so as to be able to drive the improvement of Service Performance of Bank where Structural Capital is a bank operational service centre as a vehicle for transformational information and knowledge (internal resource - IC-intellectual capital) and bank service to customers / customers (external resources).

7. Improving the quality of Human Capital will not be able to move the level of Customer Satisfaction without going through mediation of Bank Service Performance. However, the professionalism of Human Capital bank does not mean anything without the support 
of Structural Capital's role which is reflected in the improvement of the quality of the Bank's Service Performance. This is the case with Bank Service Performance and Customer Satisfaction. Qualified Human Capital will not cause an increase or decrease in the level of Customer Satisfaction, although it is stated that Human Capital is a dominant key component as a driver of Customer Satisfaction level. But otherwise Human Capital will be able to increase the level of Customer Satisfaction if mediated or bridged through Quality Service Performance.

8. Improving the Service Performance of the Bank may increase the level of Customer Satisfaction. The performance of Bank Services is a reflection of the performance of Human Capital, Relational Capital and Structural Capital which are integrated as internal resources

\section{B. Recommendations}

Based on the results and limitations of this study, there are some suggestions that can be given to academics and practitioners in developing academic ability in line with the development of science related to this research topic, are as follows:

1. Further research is needed to fill the research gap by increasing the number of research samples and involving other types of banking services industry or non-bank financial services to get more comprehensive and comparative results and better results.

2. Conducting research by examining more in the dimensions of independent variables of research in relation to the creation of intellectual asset value-corporate performance from aspects of organizational culture and leadership.

\section{Acknowledgment}

Thanks to Bank Pembangunan Kalteng (BPK) for their support and recommendation.

\section{References}

[1]. Bontis N. (1998). "Intellectual capital : an explanatory study that develops measures and models", Managements Decision, Vol. 36 No. 2, pp $63-76$.

[2]. Bontis N. (1999). "Managing organizational knowledge by diagnosing intellectual capital: farming and advancing the state of the field", International Journal of Technology Management, Vol. 18 Nos $5-8$, pp. $433-62$.

[3]. Bontis N., Keow, W. and Richardson, S. (2000). "Intellectual capital and business performance in Malaysian industries", Journal of Intellectual Capital, Vol. 1 No. 1, pp. 85 - 100.

[4]. Bontis, N. (2001). "Assessing knowledge assets : a review of the models used to measure intellectual capital”, International Journal of Management Review, Vol. 3 No. 1, pp. 41 - 60.

[5]. Bontis, N. and Fitz-enz, J. (2002). "Intellectual capital ROI: a causal map of human capital antecedents and consequents", Journal of Intellectual Capital, Vol. 3 No. 3, pp 223 - 47.

[6]. Bontis, Nick., Nicola C. Dragonetti., Kristine, Jacobsen., and Goran, Ross. (1999). "The Knowledge Toolbox: A Review of The Tools Available To Measures and Manage Intagible Resources", European Management Journal, Vo. 17. No. 4, pp. 391 - 402.

[7]. Brinker, Barry. (2000). "Intelektual Capital: Tomorrows Assets, Today's Challenge", http://www.cpavision.org/vision/wpaper05rb.cfm. 
[8]. Brooking, A. (1997). The Management Intellectual Capital. Long Range Planning, 30 (3), 364-365

[9]. Brady, M.K., J. Joseph Cronin., Brand, R.R. (2002). "Performance-only of Service Quality: A Replication and Extension”. Journal of Business Research, 55 pp. 17-31.

[10].Chen, J., Zhu, Z, and Xie, H.Y. (2004). "Measuring intellectual capital: a new model and empirical study", Journal of Intellectual Capital, Vol. 5 No. 1, pp. 195 - 212.

[11].Chin, W.W. (1998b). "The partial least squares approach to structural equation modeling", in Marcoulides, G.A. (Ed), Modern Methods for Business Research, Lawrence Erlbaum Associates, Mahwah, NJ.

[12].Chin, W.W. (2001). PLS - graph user's guide, Version 3.0 (unpublished).

[13].Drucker, P.F. (1999). "Knowledge-worker productivity: the biggest challenge", California Management Review, Vol. 41 No. 2, pp. 79 - 94.

[14].Edvinsson, L., and Malone, M.S. (1997). “Intellectual Capital: Realizing Your Company”s True Value by founding it Hidden Brainpower. New York: Harper Business.

[15].Ferdinand, A. (2006). Metode Penelitian Manajemen: Pedoman Penelitian Untuk Penulisan Skripsi, Tesis dan Disertasi Ilmu Manajemen, Edisi Kedua, Penerbit Balai Penerbit UNDIP, Semarang, ISBN 979-704-254-5, Bab.3, hal. 91-101.

[16].Fuad Mas'ud. (2004). Survai Diagnosis Organisasional Konsep \& Aplikasi, Penerbit Universitas Diponegoro, ISBN : 979704.246.4.

[17]. Ghozali, I. (2006). Structural Equation Modeling Metode Alternatif Dengan Partial Least Square, PLS, Edisi 2006, Badan Penerbit UNDP, Semarang, ISBN 979-704-254-5.

[18].Hartono, B. (2001). Intelektual Capital: "Sebuah Tantangan Akuntansi Masa Depan, Media Akuntansi", Edisi 2, Thn VIII, Oktober, hal 65-72.

[19].Handi, Irawan D. (2003). 10 Prinsip Kepuasan Pelanggan, Paradigma baru merebut hati pelanggan untuk memenangkan persaingan, Cetakan Ketiga, Penerbit PT. Alex Media Koputindo Kelompok Gramedia - Jakarta.

[20].Hitt, Michael A., R. Duane Ireland., H. Rrobert E. (2007). Konsep Manajemen Strategis Daya Saing \& Globalisasi. Salemba Empat, Jakarta.

[21].Idayanti, (2008). Pengaruh Kepribadian, Keluarga, Human Capital terhadap Karir dan Kinerja Manajer (Studi Perspektif Gender pada Perbankan di Makassar). Disertasi. Program Doktor Ilmu Manajemen Fakultas Ekonomi Universitas Brawijaya. Malang.

[22].Info Bank. 2008. Perbankan dan Keuangan, Edisi Desember, No.357, Vol. XXIX

[23].J. Knight, Daniel. (1994). "Leveraging IC Requires A Company to Become A knowledge-Based organization and to revise intensitas Performance Measures Accordingly", Strategy \& Leadership, March/April, pp. 23-25.

[24].J. Joseph Cronin, JR and Steven A. Taylor. (1994). "Servperf Versus Serqual: Reconciling Performance-Based and Perceptions-Minus-Expectations Measurement of Service Quality", Journal of Marketing, January, Vol.58, pp. 125-131.

[25].J. Cronin, JR., Brady, M.K., Hult, G.TM. (2000). “Assessing the Effect of Quality, Value, Customer Satisfaction on Consumer Behavioral Intentions in Service Environments", Journal of Retailling, Volume 76(2), pp. 193-218.

[26].Klein, K.L. (1998) The Strategic Management of Intellectual Capital. Boston: ButterworthHeinemann. 
[27].Knight, D.J. (1999). "Performance Measure for Increasing Intellectual Capital". Strategy and Leadership, 29 (1), 22-28.

[28].Knight, D.J. (1994). "Leveraging IC Requires A Company to Become A knowledge-Based organization and to revise intensitas Performance Measures Accordingly", Strategy \& Leadership, March/April, page 23 - 25.

[29]. Kotler Philip dan Armstrong Gary. (2008). Prinsip-prinsip Pemasaran, Jilid 1, Ediasi 12, Penerbit Erlangga-Jakarta.

[30].Lev, Baruch and Stefano, Zambon (2000). "Intangibles \& Intellectual Capital : Accounting \& Managing Issues for The new Economy", European Accounting Review-Call for Papers, Vol.9, Issue no. 4 , http://www.rutgers.edu/accounting/raw/aaa/market/monograph33.htm.

[31].Luthy, David H. (2000). "Intellectual Capital and It's Measurement". http://www.bus.osakaca.ac.jp/aapira98/archives/htmls/25.htm.

[32]. Macoby, M. (1999). "Building cross-functioinal capability: what is really takes", Research Technology Management, Vol. 42 No. 3 pp. $56-8$.

[33]. Malone, Michael S. (1997). "New Metrics For A New Age: Two Experts Want This In Your Next Annual Report", Forbes ASAP, April 7, page 40-41.

[34].Maar, B and Chatzkel, J. (2004). "Intellectual Capital at The Crossroads: Managing, Measuring, and Reporting of IC", Journal of Intellectual Capital, Vol. 5 No. 2, pp. 224 - 9.

[35].Maar, B. (2008). “Technical Matters: Intangible Asset Measurement”, Financial Management: Jun 2008; ABI/INFORM Global, p.32.

[36].Mayo, A. (2001). The Human Value of the Enterprise: Valuing People as Assets: Monitoring, Measuring, Managing, Naperville Nicholas Brealey, London.

[37].Mouritsen (2000). Intellectual Capital Statements and Knowledge Managements : Measuring, Reporting, Acting, Australia accounting Review.

[38].___ (2001). Toward A Framework For Intellectual Capital Statements, Denmark.

[39].Moon, Y.j. and Kym, H.G., (2006). A Model for The Value of Intellectual Capital. Canadian Journal of Administration Sciences, 23(3), 253-269

[40].Maddern, H., Maull R. and Smart, A. (2007). Customer Satisfaction and Service Quality in UK Financial Services. International Journal of Operation \& Productions Maagement, Vol. 27, No. 9, pp. 908-1019.

[41].Nahapiet, J. and Ghosal, S. (1998). Social Capital, Intellectual Capital and The Organizational Advantage. Academy of Management Review, 23(2), 242-267.

[42].Partanen, Timo (1998). Intellectual Capital Accounting: Some Steps Towards A Conceptual Framework For The Valuations Of Intangible Assets, Master Thesis, Department of Accounting and Finance, Helsinky School Of Economics And Business Administration.

[43].Porter, M. (1985). Competitive Advantage: Creating and Sustaining Superior performance, Free Press, New York, NY.

[44].Porter, M. (1981). “Towards A Dynamic Theory of Srategy”, Strategic Managemt Journal, Vol. 12, Winter, Special Issus, pp. p5-117.

[45].Porter, M. (1996). Competitive Strategy: Technique for Analyzing Indutries and Competitors, New York: The Free Press, A Devition of Maxmillian, Inc. 
[46].Prusak, L. (2001). Where Did Knowledge Management Come From?. Armonk: IBM System Journal. Vol.40, p.1002-1007.

[47].Pfeffer, J., B W. Soetjipto., T. Hani Handoko., D. Ancok., S. Dharma., K. Peniwati., A. Pradiansyah., W. Adi PS (2003). Paradigma Baru Manajeman Sumber Daya Manusia. Edisi ke 2, keempat, Penerbit Amara Books, Yogyakarta.

[48].Roos, J., Roos G., Nocola C. Dragonetti, and Leif Edvinsson (1997). Intellectual Capital Navigating The New Business Landscape, London: MacMillan Press Ltd.

[49]. Robbins Stephen P. dan Judge TA. (2008). Perilaku Organisasi; Organizational Behavior, Edisi 12, Penerbit Salemba Empat-Jakarta.

[50]. Robbins Stephen P. (2007). Perilaku Organisasi, Edisi Lengkap, ke 10, Cetakan II, Penerbit PT. Macananjaya Cemerlang, Indonesia

[51].Saint-Onge, Hubert (1996). "Tacit Knowledge: The Key To The Strategic Aligment of Intellectual Capital”, Strategic Leadership, (March/April), page 10.

[52]. Satyo (2000). "Sulitnya Mengkuantifikasi Modal Intektual”, Media Akuntansi, (Oktober), No. 1/Thn VII : $45-46$.

[53]. Sekaran, U (2006). Research Methods For Business, Metodologi Penelitian untuk Bisnis, Edisi keempat, Salemba Empat-Jakarta.

[54].Steward, T.A. (2001a). The Wealth of Knowledge: Intellectual Capital and the Twenty-First Century Organization, Currency, New York, NY.

[55]. Stewart (1994). "Your company's Most Valuable Assets Intellectual Capital”, Fotune, (October) : page $68-74$

[56].Sullivan, P.H. (1998). Profiting from Intellectual Capital: Extracting Value from Innovation, Wiley, New York, NY.

[57].Sullivan, Patrick H. (2000). "A Brief History Of The Intellectual Capital Movement", http://www.brookings.org.es/research/projects/intangibles/ icexsum.pdfruch_luv.

[58].Sveiby, K.E. (1998). "Intellectual capital and knowledge management", available at: www.sveiby.com/articles/IntellectualCapital.html (accesed April 1, 2004).

[59].Sveiby, (2001). "Methods for Measuring Intangible Assets", http://www.sveiby.com/articles/IntagibleMethods.htm.

[60]. Sulastri, (2005). Pengaruh Intellectual Capital dan Social Capital terhadap Kompensasi Karyawan dan Kinerja Perusahaan pada Perusahaan Manufaktur yang Listing di Bursa Efek Jakarta.

[61].Sangkala, (2006). Intellectual Capital Management: Strategi Baru Membangun Daya Saing Perusahaan. Edisi Pertama, Penerbit Ikatan Penerbit Indonesia DKI Jakarta. ISBN: 979-3274-29-8.

[62]._ (2006). Strategi Pengelolaan Modal Intelektual Pada Perusahaan Periklanan di Jakarta. YAPENSI-Jakarta.

[63]. Sugiyono (2008). Metode Penelitian Bisnis (Pendekatan Kuantitatif, Kualitatif dan R\&D), Cetakan Kesebelas, Januari, Penerbit Alphabeta, Bandung.

[64].Zeithaml, Berry and Parasuraman (1996). The Behavior Concequences of Service Quality. Journal of Marketing, 